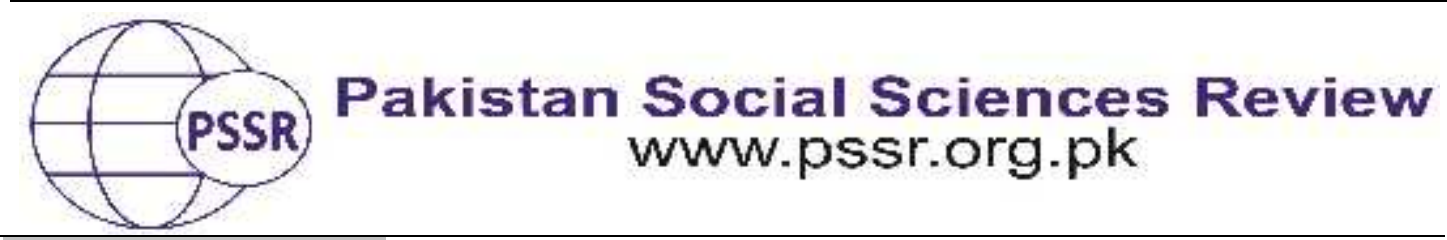

RESEARCH PAPER

\title{
COVID 19 and Changing Facets of Stress: A Psychological Study of Stress-Oriented People
}

\author{
Hina Rafique ${ }^{1}$ Farhana Tabassum ${ }^{2}$ Bushra Munawar ${ }^{3}$
}

1. Assistant Professor, Department of English, Govt. P. G. College (W) S/T Gujranwala, Punjab, Pakistan

2. Senior Lecturer, University Institute of Medical Lab Technology, Faculty of Allied Health Sciences, University of Lahore, Lahore, Punjab, Pakistan

3. Adjunct Professor, Kean University, NJ, The United States of America

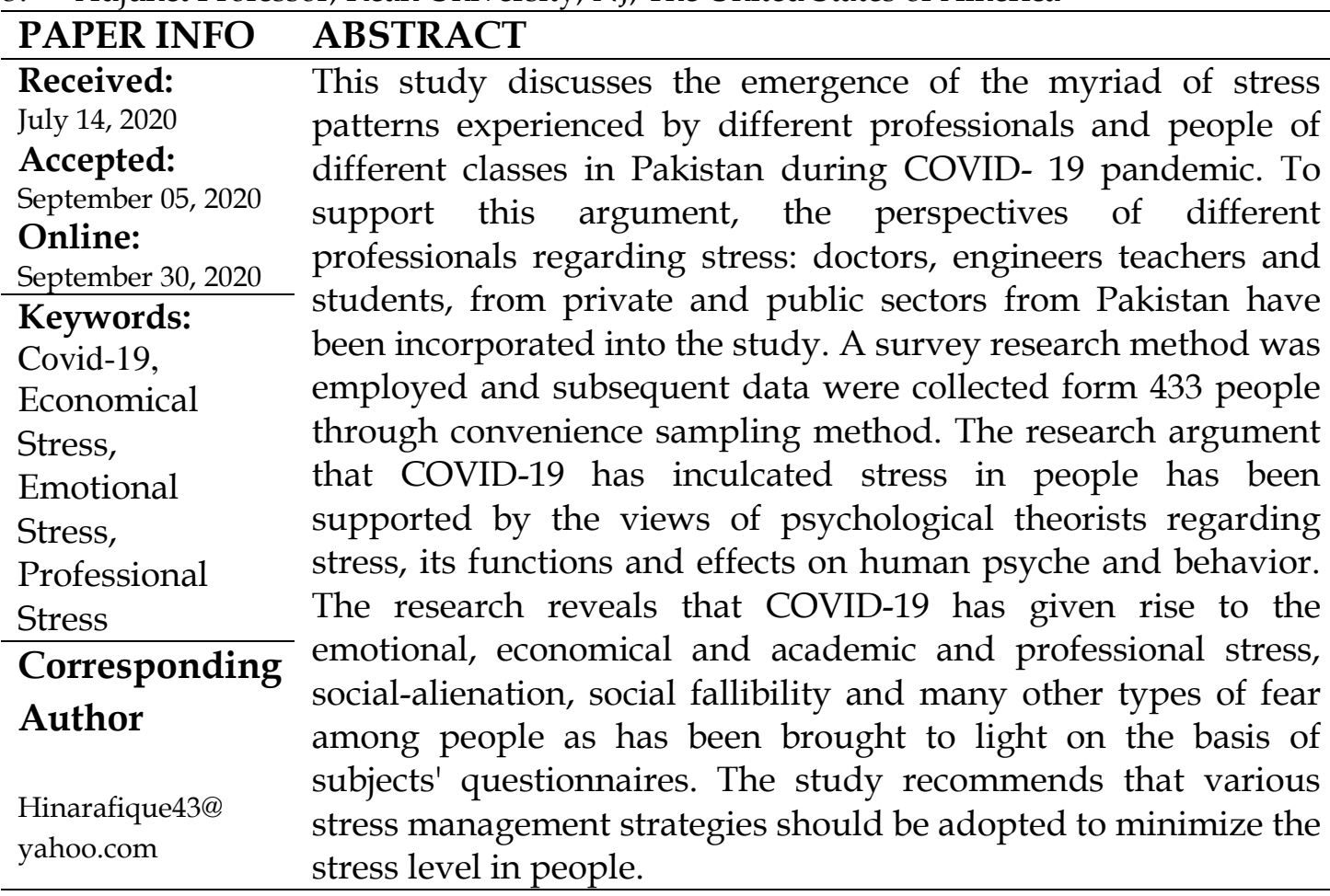

\section{Introduction}

The devastating impact of COVID-19 on health, culture, education, economy, tourism, human relationships and other aspects of human life has come to surface in past months, globally. There is hardly any domain left which remains unaffected by impact of COVID-19. Human psyche is perhaps the most affected domain in this biological warfare. Many psychological changes have been observed in human behaviors. Stress is definitely a psychological instigator behind these disturbed human behaviors. The notion of stress as a psychological factor has been elaborated, discussed, experimented upon and researched by psychologists, scholar and researchers since decades. It has been a source of various mental illness, emotional 
tragedies, physical violence, and psychological and physical health deterioration since decades. Stress is one of the most important and complex areas of study in Psychology, Sociology and in Mental Health Research in modern times. Its depth, diversity and magnitude depend on transculturalism, gender-discrimination, human interaction with ecological environment and complexity of human relations. It has emerged as a threat to health, well beings and proper development of human personalities.

Hence, this research study negotiates that how COVID-19, as a disease has introduced diversified stress patterns in human beings; extending the range of stress patterns from their personal to social and professional lives. This study has been conducted to trace different types of stress among doctors, teachers, students, and engineers on six stressors; physiological, social, psychological, academic, professional and financial. Nevertheless, this study brings to light the fact that novel types of stress have been observed in humans during COVID 19 rapid spread in Pakistan.

\section{Literature Review}

This section of the research paper discusses the significant literature on stress and brings to light the relevant research conducted on stress and psychological effects of COVID-19 pandemic.

\section{Stress \& its Approaches}

"Stress is a normal psycho-physiological response to events which result in the sense of threat, sadness, Dysphoria, and imbalance in people (Shalev, Yehuda, \& McFarlane, 2000,p.11)."In medicine and Biology, stress is called to any physical, psychological, and/or emotional factor which results in physical, and/or psychological tension" (McEwen ,2007, p.13). "Stress is bodily response to any demand. It could be caused by either good or bad experiences" (Kumari, et al.,2009, p.15).And "Stress is described as a sense of being overwhelmed, worry, destruction, press, exhaustion, and lethargy. Therefore, stress can influence people of every age, sex, race, and situation and can result in both physical and psychological health"(American Psychiatric Association, 2014,p.12).Many researchers are of the opinion that stress is not always negative as it fosters a spirit of struggle for achievement in humans when it is in moderate form. However, it becomes negative when a person does not employ the stress management strategies effectively to control it.

Shahsavarani, et al (2015) state that stress is a feeling of mental pressure and stress in low degree can be healthy. It is either caused by external elements or by the individual's internal system. If it is caused by an individual's psychological pattern it can result in anxiety, and other negative emotions and feelings such as pressure, pain and sadness, etc., and can trigger serious psychological disorders in humans such as post-traumatic stress disorder (PTSD).There are three approaches to stress; 
response-based, cognitive-based and cognitive-transactional based. Response-based stress is based on the response of human beings in context of their environment in which they are exposed to. This approach distinguishes between stressor (stimulus) and stress (response) and Hans Selye is a representative of this approach. This approach is prevalent in medical studies and biological studies. This stress response has the following mechanism.

This stress response follows a typical three stage pattern which is similar both in animals and humankind. Selye named this pattern as General Adaptation Syndrome (GAS) which comprises alarm reaction (fight or flight response), resistance stage (bearing chronic stress and active use of body resources), and exhaustion stage (onset of tissue damages, onset of disease, and evacuation of body resources) (Shahsavarani, et al. 2015,p.232).

The second approach to stress is stimulus-based approach and Homes and Rahe are its chief proponents. In this approach, the severity of the stressor is focused and "it has been revealed that the average amount of needed effort to overcome some event might be a suitable index of the severity"(Shahsavarani, Abadi\&Kalkhoran,2015,p.232) but it ignores the individual, biological, cognitive, and emotional factors. Third is Transactional-cognitive process. There is an equal importance of stressor and individual in this perspective. It considers the interaction among cognition, emotions, and biological reactions of a human being. Lazarus $\&$ Folkman are its chief proponents. The proponents of this approach propose that stress occurs as an intruding factor of the relation between an individual and environment and both influence each other.

Transactional-cognitive process considers stress as a specific relation between individual and her/his surrounding environment in which individual perceives the demands of the surrounding environment pressing and overwhelming on her/his resources and hence, threatening to her/his health. This perspective of stress has three meta- theoretical assumptions of transaction, process, and context, respectively. Stress is ever-changing. Authors of this perspective consider stress as an active and progressive process which includes causal antecedents, intervening processes, and influence (Shahsavarani, et al. 2015, p.232).

Stress can be classified on three categories; "according to the nature of the stressor (physiological stress and psychological stress); according to stress influence on the individual( positive impact and negative distress); according to exposure duration to stressor (acute stress(short term) and chronic stress (long term) "(Shahsavarani, et al.,2015,p.232).Furthermore, the domain of stress has developed from biological to socio- psychological in modern times. Stress is believed to be the descendent of 'anxiety'. There are many factors which cause stress in humans. Likewise, the influence of culture on human beings is also an important factor in triggering stress as culture with its various elements (gender-discrimination, 
religion, ideology, certain traditions and practices, Media, handling of minorities etc.) causes stress in citizens of a particular nation.

\section{Existing Body of Literature on Stress due to COVID-19}

In the context of stress and stressors faced by doctors, teachers, students and engineers in wake of COVID 19 scenario, few conducted researches have been cited here. Misra\& G. Castillo (2004) in their research negotiated about the academic stress among university and college students. They examined five categories of academic stressors (i.e., frustrations, conflicts, pressures, changes, and self-imposition) and furthermore described reactions of students to other stressors (i.e., physiological, emotional, behavioral, and cognitive) by doing experiments on the American and International students. They argue that American and international students are different in their perceptions and reactions to academic stressors. It might be because of their culture differences and cultural variables. Furthermore, they quoted Winkelman (1994) who was of the opinion that when students experience excessive or negative stress, they experience physical and psychological reactions to stressors. Resultantly, excessive stress causes physical impairments, and it is common to find such students who are facing lack of energy, loss of appetite, headaches, or gastrointestinal due to stress (Misra \& Castillo, 2004,p.133) .

Yikealo, et al. (2018) presented their study to diagnose the level of stress found among university students. They ventured to explore this psychological phenomenon to figure out the stress level in college students on five stressors; physiological, social, psychological, academic, and environmental. They talked about the co-relation between students' level of stress and their academic performance. Besides, they highlighted the stress difference according to gender, as they thought that women were more likely to fall victim to stress because they tend to cope with situations emotionally and non-rationally as compared to men (Yikealo, et al., 2018, p.04). They state that "the sources of stress and magnitude of stress among students are not consistent across the studies" (p.03). It implies the fact that with changing situations, the stress level changes.

Urooj, et al (2020) in their research explored the fears and stress faced by doctors and medical staff amid their exposure to this disease and its resultant affects on healthcare staff. Their research highlighted and directed toward the challenges, health care system in Pakistan faced by this pandemic. Their research proposes findings according to which:

"Fear of complications of disease in patients was $60.36 \%, 79.7 \%$ feared infecting family members, $27.9 \%$ feared not diagnosing Covid-19 positive patient, $63 \%$ rapid spread of disease and $28.8 \%$ becoming a carrier. A survey conducted in China during the initial outbreak of COVID-19 found that $53.8 \%$ of respondents rated the psychological impact of the outbreak as moderate or severe, $16.5 \%$ reported moderate to severe depressive symptoms, $28.8 \%$ reported moderate to 
severe anxiety symptoms, and $8.1 \%$ reported moderate to severe stress levels (Urooj, et al., 2020, p.41).

Moreover, Collie \&Martin (2020) have talked about the notion of teachers' well-being during COVID-19 and the role of administration and educational leaders to support teachers in their research. They come forward with a different perspective. They propound that the teachers who share strong relations with their colleagues and students are less the victim of this pandemic and fear. Besides, the teachers who have strong ability to adapt in a new situation have also to be in great well-being. However, "autonomy supportive leadership behaviours" (05) are instrumental in promoting teacher's well-being and developing strong relations with their students (Collie\& Martin, 2020, p.05).

Fardin (2020) in his short review has accumulated the similar studies conducted in China after COVID 19 outbreak in perspective of the stress-oriented phenomenon among people. According to his review, the emergence of elements of distress, stress, anxiety, PSD (post stress disorder) has been observed in the Chinese People. He has also talked about different types of fear people are facing during this pandemic; fear of losing their loved ones, friends and social acquaintances during this pandemic. According to one of the studies presented in this review, women are more likely to fall victim to stress than men (Fardin, 2020).

Etxebarria, et al (2020) in their research explored the prevailing stress and anxiety in Spain during COVID-19 breakthrough using DASS (depression, anxiety stress scale).Their study presented the spotting of stress symptoms in the Spanish citizens even when they stayed at home. In short, it is informative study to know about the psychological effects of this disease on the health of Spanish people.

Moreover, Gautam and Sharma (2020) opine about the psychological afteraffects of this pandemic in their research, particularly about students, teachers and academic faculty. They expressed their views that teachers and students are facing academic fiasco as students are confused because of rapid change of situation and the burden of attending online classes. Teachers are facing financial crisis as they are not being paid properly and they are not fully equipped with online teaching and instructing strategies now. Consequently, they are in jeopardy as their future lacks direction and educational planning. The researchers in labs are also confused and facing stress.

This is exploratory research. Quantitative-cum qualitative approach has been used in this research that fits to address the problem of the research. A survey research method was used to elicit responses from the participants of the study. The datacollection process started from 1 ${ }^{\text {st }}$ May 2020 and it completed on 8 June 2020.

Population and sampling: The study involved diverse population such as doctors (24), engineers (100), educators (107) and students (201)from different public and private institutions in Gujranwala, Faisalabad, and Lahore, Pakistan. Through snowballing sampling techniques, the link of the online questionnaires was shared 
with respective respondents via different social network platforms such as WhatsApp and Facebook.

Questionnaires: For data collection, 4 separate semi-structured and closedended online questionnaires were developed to report the responses of the respondents on questionnaire items. The questionnaires for the engineers comprised of (13 items), for doctors (18 items), for educators (15 items), and for students (20 items). They provided information on different types of stress such as psychological, financial, social, academic, professional and environmental stress as experienced by respondents.

Data Analysis: The data obtained from online survey questionnaires were tabulated, analyzed and interpreted statistically. For data analysis, the statistical software Statistical Package for Social Sciences (SPSS) version 25 was used.

\section{Results and Discussion}

Participants' Demographic Characteristics (N=432)

\begin{tabular}{|c|c|c|c|}
\hline \multirow[t]{9}{*}{ Engineers } & Demographic & Features & $\mathbf{N}(\%)$ \\
\hline & Age (years) & & \\
\hline & Mean 23.26 & & \\
\hline & $\mathrm{SD} \quad+4.631$ & & \\
\hline & Gender & Male & 10(10) \\
\hline & & Female & $90(90)$ \\
\hline & Education & Bachelor & $34(34)$ \\
\hline & & Master & $60(60)$ \\
\hline & & Other & $6(6)$ \\
\hline \multirow[t]{11}{*}{ Doctors } & Age (years) & & \\
\hline & Mean 26.33 & & \\
\hline & $\mathrm{SD} \quad+4.270$ & & \\
\hline & Gender & Male & $5(20.8)$ \\
\hline & & Female & $19(79.2)$ \\
\hline & Weekly duty Hours & $35-44$ & $15(62.5)$ \\
\hline & & $45-60$ & $8(33.3)$ \\
\hline & & more than 60 & $1(4.2)$ \\
\hline & Sleeping Status (hours) & 6 to 8 & $16(66.7)$ \\
\hline & & Less than 8 & $7(29.2)$ \\
\hline & & more than 8 & $1(4.2)$ \\
\hline \multirow[t]{7}{*}{ Teachers } & Age (years) & & \\
\hline & Mean 25.12 & & \\
\hline & $\mathrm{SD} \quad+8.555$ & & \\
\hline & Gender & Male & $23(21.5)$ \\
\hline & & Female & $84(78.5)$ \\
\hline & Education & Bachelor & $84(78.5)$ \\
\hline & & Master & $23(21.5)$ \\
\hline \multirow[t]{3}{*}{ Students } & Age (years) & & \\
\hline & Mean 20.49 & & \\
\hline & SD $\quad+2.328$ & & \\
\hline
\end{tabular}




\begin{tabular}{|c|c|c|c|}
\hline & Male & 61(30.3) \\
\hline \multicolumn{2}{|c|}{ Gender } & Female & $140(69.7)$ \\
\hline In Which semester & $1^{\text {st }}$ & & $28(13.9)$ \\
\hline are you studying? & $2^{\text {nd }}$ & & $75(37.3)$ \\
\hline & $3^{\text {rd }}$ & & $0(0)$ \\
\hline & $4^{\text {th }}$ & & $17(8.5)$ \\
\hline & $5^{\text {th }}$ & & $1(0.5)$ \\
\hline & $6^{\text {th }}$ & & $8(4)$ \\
\hline & $7^{\text {th }}$ & & $0(0)$ \\
\hline & $8^{\text {th }}$ & & $72(35.8)$ \\
\hline What's your degree & Graduate & & $108(53.7)$ \\
\hline level? & Post Graduate & & $93(46.3)$ \\
\hline
\end{tabular}

Participants' Characteristics: Four hundred and thirty-two respondents participated in the study. The mean age of engineers was $23.26+\mathrm{SD} \pm 4.631$. Most of the respondents $(90 \%)$ were predominantly females and a noticeable percentage of the respondents $(60 \%)$ was master degree holders. The mean age of doctors was $26.33+\mathrm{SD} \pm 4.270$. Majority of them $(79.2 \%)$ were primarily females and $(62.5 \%)$ of doctors were working from 35 to 44 hours per week. The mean age of educators was $25.12+$ SD \pm 8.555 and mainly (78.5\%) females participated in the study. While (78.5\%) among them were bachelors. Moreover, the mean age of students was 20.49 $+\mathrm{SD} \pm 2.328$. Majority of them (69.7\%) were female students and (53.7\%) respondents among them were doing graduation. The remaining sections of the four online questionnaires were analyzed and presented in following four different tables.

Table 1

Responses of the Engineers ( $N=100)$

\begin{tabular}{lcc}
\hline \multicolumn{1}{c}{ Items } & Yes & No \\
\hline $\begin{array}{l}\text { 1. 1 I am afraid that whether we ever get back to our normal } \\
\text { routine. }\end{array}$ & $84(84 \%)$ & $16(16 \%)$ \\
\hline 1. 2 I am afraid of being downsized. & $68(68 \%)$ & $32(32 \%)$ \\
\hline 1. I I am afraid that I may not continue my job in future. & $60(60 \%)$ & $40(40 \%)$ \\
\hline 4 I am afraid of losing exclusive (offering good prospects) projects. & $67(67 \%)$ & $33(33 \%)$ \\
\hline $\begin{array}{l}\text { 1. 5 am afraid of losing economic stability because of losing good } \\
\text { projects. }\end{array}$ & $64(64 \%)$ & $36(36 \%)$ \\
$\begin{array}{l}\text { 1. 6 I am afraid that I will not be given routine increment in my } \\
\text { salary in future }\end{array}$ & $76(76 \%)$ & $24(24 \%)$ \\
\hline $\begin{array}{l}\text { 1. } 7 \text { I am afraid of losing my health fitness due to restlessness and } \\
\text { mental tension. }\end{array}$ & $77(77 \%)$ & $21(21 \%)$ \\
\hline $\begin{array}{l}\text { 1. 8 I am afraid of an alarming rapid spread of Corona Virus in our } \\
\text { country. }\end{array}$ & $92(92 \%)$ & $8(8 \%)$ \\
\hline $\begin{array}{l}\text { 1. 9 I am afraid of losing friends, co-workers, my family and } \\
\text { relatives. }\end{array}$ & $84(84 \%)$ & $16(16 \%)$ \\
\hline
\end{tabular}

Table 1 demonstrates the responses of the engineers regarding different types of stress that they were facing during COVID-19. A majority of respondents $84(84.5)$ 
seem apprehensive that whether they would ever get back to normal routine or not (item 1.1). Similarly, a little more than half of the respondents $68(68 \%)$ were afraid of being downsized as it has become a common practice in different private and public sectors due to pandemic crisis (item 1.2). A noticeable percentage of respondents $76(76 \%)$ exhibited financial stress that they would not be provided any increment for their salaries due to decline and losses in various projects (item1.6). A great majority of respondents $92(92 \%)$ also reported mental stress and anxiety on alarming spread of the novel Corona virus in Pakistan (item 1.8). Lastly, a large number of respondents $84(84 \%)$ was experiencing emotional and psychological stress on account of losing their friends, colleagues, relatives and family members due to virus (item 1.9).

Table 2

Responses of the Doctors ( $\mathrm{N}=\mathbf{2 4})$

\begin{tabular}{|c|c|c|}
\hline Items & Yes & No \\
\hline 2.1 I am afraid of getting infection during working hours. & $19(79.2 \%)$ & $5(20.8 \%)$ \\
\hline $\begin{array}{l}\text { 2.2 I feel depressed when I find myself amongst the infected } \\
\text { (COVID-) patients. }\end{array}$ & $18(75 \%)$ & $6(25 \%)$ \\
\hline 2.3 I am afraid that I may infect my family if I get infected. & $22(91.7 \%)$ & $2(8.3 \%)$ \\
\hline $\begin{array}{l}2.4 \text { I am afraid of rapid spread of Corona Virus in our } \\
\text { country. }\end{array}$ & $24(100 \%)$ & $0(0 \%)$ \\
\hline $\begin{array}{l}2.5 \text { I am afraid of losing friends, co-workers, family and } \\
\text { relatives. }\end{array}$ & $20(83.3 \%)$ & $4(16.7 \%)$ \\
\hline $\begin{array}{l}2.6 \text { I am afraid that I may be suffering from Corona } \\
\text { unknowingly. }\end{array}$ & $13(54.2 \%)$ & $11(45.5 \%)$ \\
\hline $\begin{array}{l}\text { 2.7 I am afraid of losing my health fitness due to restlessness, } \\
\text { mental tension and overwork. }\end{array}$ & $16(66.7 \%)$ & $8(33.3 \%)$ \\
\hline $\begin{array}{l}2.8 \text { I am afraid of losing my job if I refuse to report to my } \\
\text { assigned job place during COVID- } 19 \text {. }\end{array}$ & $12(50 \%)$ & $12(50 \%)$ \\
\hline $\begin{array}{l}2.9 \text { I am afraid of being called disloyal to my country if I do } \\
\text { not do my job in this time of need. }\end{array}$ & $17(70.8 \%)$ & $7(29.2 \%)$ \\
\hline $2.10 \mathrm{I}$ am afraid that I may not continue my job in future. & $6(25 \%)$ & $18(75 \%)$ \\
\hline
\end{tabular}

Table 2 presents the responses of the respondents (doctors) on different types of stress that they were facing during outbreak. A majority of respondents 19(79.2\%) reported psychological stress of contracting the virus while looking after infected patients during working hours (item 2.1). Similarly, a large number of the respondents also reported mental and physiological stress and fear not only on getting infection but also spreading that infection to their family members and other acquaintances (item 2.3). Likewise, most of the respondents 20(83.3\%) exhibited emotional stress of losing their family, friends and colleagues (item 2.5) due to COVID- 19. The findings also revealed that over half of the respondents 13(54.2\%) were also having stress that they might be suffering from Corona (item 2.6). Similarly, a noticeable number of percentage of respondents $16(66.7 \%)$ also expressed fear and anxiety pertaining to loss of health fitness due to disquiet and 
overwork (item 2.7). During current scenario, the role of the doctors and medical staff is crucial. The study revealed that the majority of the respondents 17(70.8\%) were also afraid of being called disloyal if they did not continue their jobs during current crisis (item 2.9). Lastly, a noticeable number of respondents $18(75 \%)$ did not have fear of losing their jobs during outbreak in the country (item 2.10).

Table 3

Responses of Educators (N=107)

\begin{tabular}{lcc}
\hline \multicolumn{1}{c}{ Items } & Yes & No \\
\hline $\begin{array}{l}\text { 3.1 I am afraid of being downsized in my Education Institute. } \\
\text { 3.2 I am apprehensive that when will we get back to normal life. }\end{array}$ & $91(83 \%)$ & $50(46.7 \%)$ \\
\hline $\begin{array}{l}\text { 3.3 I am afraid whether my family, friends, relatives and } \\
\text { colleagues will remain safe and sound or not. }\end{array}$ & $90(84.1 \%)$ & $17(15 \%)$ \\
\hline $\begin{array}{l}\text { 3.4 I am apprehensive that how many people around me are } \\
\text { able to meet their both ends due to lock-down situation. }\end{array}$ & $94(87.9 \%)$ & $13(12.1 \%)$ \\
\hline 3.5 I am afraid of using new technology for online classes. & $65(60.7 \%)$ & $42(39.3 \%)$ \\
\hline $\begin{array}{l}\text { 3.6 I am afraid of delivering online video lectures. } \\
\text { 3.7 I am afraid of losing interaction with new linguistic, literary } \\
\text { and in use language trends because of not attending } \\
\text { conferences. }\end{array}$ & $80(74.8 \%)$ & $27(25.2 \%)$ \\
\hline $\begin{array}{l}\text { 3.8 I am afraid of deduction of monthly conveyance allowance } \\
\text { from my salary. }\end{array}$ & $54(50.5 \%)$ & $53(49.5 \%)$ \\
\hline $\begin{array}{l}\text { 3.9 I am afraid of extending my economical pressure because of } \\
\text { internet expenditure to be utilized in online classes. }\end{array}$ & $74(69.2 \%)$ & $33(30.8 \%)$ \\
\hline $\begin{array}{l}\text { 3.10 I am afraid of becoming lazy, inactive and non-professional } \\
\text { because of change in my routine. }\end{array}$ & $95(88.8 \%)$ & $12(11.2 \%)$ \\
\hline 3.11 I am afraid of losing my dressing style. & $48(44.9 \%)$ & $59(55.1 \%)$ \\
\hline 3.12 I am afraid of gaining weight because of staying at home. & $75(70.1 \%)$ & $32(29.9 \%)$ \\
\hline
\end{tabular}

Table 3 shows responses of the educators on different types of fear that they might or might not be facing during COVID-19. The findings revealed that a little more than half of respondents $57(53.3 \%)$ had a financial stress of being laying off because many higher institutions have already started downsizing to deal with their financial strain (item 3.1).A majority of respondents $91(85 \%)$ were apprehensive that when would they go back to normal life and the current phase of uncertainty has become great source of fear and stress amongst respondents (item 3.2). Similarly, a great number of respondents $90(84.1 \%)$ were also having social stress regarding their family, relatives, friends and coworkers' health and safety due to virus (item 3.3). Likewise, a noticeable percentage of the respondents $65(50.7 \%)$ reported mental stress due to online classes that they had never experienced before Corona virus (item 3.5). Another finding pertaining to online video lectures exhibited that a majority of the respondents $69(64.5 \%)$ had psychological stress of taking online video lectures (item 3.6). Correspondingly, a remarkable number of the respondents $74(69.2 \%)$ also disclosed financial stress on extending their internet expenditures due to online classes (item 3.9). Lastly, a great number of respondents 95(88.8\%) reported mental and health-oriented stress due to sedentary and passive living style due to infectious COVID-19. 
Table 4

Responses of Students $(\mathrm{N}=\mathbf{2 0 1})$

\begin{tabular}{|c|c|c|}
\hline Items & Yes & No \\
\hline $\begin{array}{l}\text { 4.1 I am apprehensive regarding the heath of my friends, relatives } \\
\text { and class fellows. }\end{array}$ & $177(88.1 \%)$ & $24(119 \%)$ \\
\hline $\begin{array}{l}4.2 \text { I feel depressed when I think whether my family and I will } \\
\text { remain safe or not. }\end{array}$ & $170(84.6 \%)$ & $31(15.4 \%)$ \\
\hline 4.3 I am apprehensive that when will we have a normal life again? & $180(89.6 \%)$ & $21(10.4 \%)$ \\
\hline $\begin{array}{l}\text { 4.4 I am afraid of being not able to complete my online quiz in the } \\
\text { allocated time. }\end{array}$ & $144(71.6 \%)$ & $57(28.4 \%)$ \\
\hline 4.5 I am afraid of internet's weak connection during quizzing. & $145(72.6 \%)$ & $55(27.4 \%)$ \\
\hline 4.6 I am afraid that I will not be able to retain my previous grades. & $155(77.1 \%)$ & $46(22.9 \%)$ \\
\hline $\begin{array}{l}\text { 4.7 I am afraid that I will not score good marks due to online } \\
\text { education system. }\end{array}$ & 157(78.1\%) & $44(21.9 \%)$ \\
\hline $\begin{array}{l}4.8 \text { I am afraid of attending online classes on Zoom video, Skype } \\
\text { and Google classroom (software). }\end{array}$ & $101(50.2 \%)$ & $100(49.8 \%)$ \\
\hline $\begin{array}{l}4.9 \text { I am afraid that online system of education will influence my } \\
\text { results negatively. }\end{array}$ & $153(76.1 \%)$ & $48(23.9 \%)$ \\
\hline $\begin{array}{l}4.10 \text { I am afraid of becoming lazy while staying at home and by not } \\
\text { physically attending my institute. }\end{array}$ & 163(81.1\%) & $38(18.9 \%)$ \\
\hline 4.11 I am afraid of becoming addict to social forums. & $114(56.7 \%)$ & $87(43.3 \%)$ \\
\hline $\begin{array}{l}4.12 \text { I am afraid of getting in out of touch with library as it will mar } \\
\text { my literary aptitude. }\end{array}$ & $126(62.7 \%)$ & $75(37.3 \%)$ \\
\hline $\begin{array}{l}4.13 \text { I am afraid of being too much homely because of household } \\
\text { chores I have to perform now }\end{array}$ & $122(60.7 \%)$ & $79(39.3 \%)$ \\
\hline $\begin{array}{l}\text { 4.14 I am afraid that the household chores will decrease my energy } \\
\text { and time for study. }\end{array}$ & $131(65.2 \%)$ & $70(43.8 \%)$ \\
\hline $\begin{array}{l}4.15 \text { I am afraid that my academic career will receive major } \\
\text { academic halt because of no exams and in timely promotion in next } \\
\text { semester/ class. }\end{array}$ & $155(77.1 \%)$ & $46(22.9 \%)$ \\
\hline $\begin{array}{l}4.16 \text { I am afraid of facing dishonest marks grading system which } \\
\text { will not be up to the mark. }\end{array}$ & $164(81.6 \%)$ & $37(18.4 \%)$ \\
\hline
\end{tabular}

Table 4 demonstrates the responses of respondents (students) on different types of stresses that they might be facing during COVID-19. The study brought to light that majority of the respondents $177(88.1 \%)$ was having a stress regarding the health of their family members, relatives, friends and class fellows (item 4.1). Similarly, a remarkable number of respondents $144(76.4 \%)$ also reported experiencing stress on their inability of completing online quizzes in the given time period (item 4.4). Likewise, in relation to academics, a noticeable number of respondents $145(72.6 \%)$ also reported stress that they faced while attempting online quizzes due to weak internet connections (item 4.5). In addition to that, a large number of the respondents $153(76.1 \%)$ also mentioned academic stress in regards to negative impact of E-learning assessment methods on their results (item 4.9). Over more than half number of respondents 114(56.7\%) expressed fear and stress addiction to social forums due to social distancing and self-isolation during outbreak 
(item 4.11).Moreover, a remarkable number of respondents $155(77.1 \%)$ reported apprehensions and stress due to complete closure of universities and resultantly there would be no exams and promotion to next semester (item 4.15). Lastly, a large majority of the respondents $164(84.6 \%)$ also revealed mental stress due to unreliable grading system in the online learning system (4.16).

The overall findings of the study revealed that COVID-19 has affected the professionals of divergent domains by variety of mental, physiological, psychological, academic, emotional and professional stress due to prevailing environment. All the respondents (engineers, doctors, teachers and students) were under psychological stress due to uncertainty of present scenario and looking for the time when things will get normalized. Likewise, all the respondents of the study exhibited major concerns and reported great mental and emotional stress pertaining to health and safety of their family members, relatives, friends, colleagues and class fellows. Similar finding was documented by Bhat et al.,(2020) in his study "A Study on Impact of COVID-19 Lockdown on Psychological Health, Economy and Social Life of People in Kashmir" and he stated that COVID-19 pandemic has caused worldwide stress and persistent anxiety amongst all people and engendered the mental health and "psychological well being of individuals from the entire community including students, casual laborers, healthcare professionals and the general population"(p.44). Fardin (2020) also discussed anxiety and psychological impact on people due to Corona outbreak. Mian (2020) also writes about the crisis that "a main reason for stress comes from a feeling of uncertainty, and if this has triggered anything on a global scale, it is a sense of moving into the unknown".

A sudden emergence of Corona virus has led to temporal cessation of work places, schools, colleges and universities in order to hinder further spread of virus. The study also spotted physiological stress that majority of the respondents from all domains were experiencing due to sedentary lifestyle which is directly associated with passivity and immobility which could lead to serious health issues. Due to unexpected crises in economy, respondents from all the domains except doctors also reported their financial and psychological stress regarding the fear of downsizing during COVID-19 pandemic. At present, the government of Pakistan has decided to lay off thousands of Pakistani Steel Mills' employees, polio workers owing to financial crisis (Shams \& S.Khan, 2020)\& (The News, 2020). Contrarily, the doctors were not suffering from any financial stress and depression due to layoffs. As in the current context, there is a huge demand of doctors and medical staff in every hospital of Pakistan.

The study also revealed that doctors were experiencing mental stress of contracting virus while working on the frontline with the infected patients. They expressed acute mental and emotional stress of being infected and further transmitting the infection to their family members. This issue has become the major concern of doctors not only in Pakistan but globally. Urooj et al., (2020) also reported similar results that "significant number of doctors expressed feelings of concern, anxiety, uncertainty and stress while working in high-risk situations" (p. 05). 
The study also brought to light that educators were also suffering from financial and economic stress due to pay reduction, extended expenditures due to internet packages for online teaching and psychological stress of online teaching with open videos which they had never experienced before. Gewertz (2020) also penned that "Educators' stress is skyrocketing during pandemic"(n.p) as they are struggling hard to grapple with unknown technology. Likewise, Cipriano\& Bracket (2020) unearthed in their study "the five most-mentioned feelings among all teachers were: anxious, fearful, worried, overwhelmed and sad" that were impacting the performance of the educators (n.p).

In the same vein, the study also indicated that students were also experiencing various stresses regarding their academic development. Majority of them manifested stress due to weak internet connection during quizzes, of losing marks due to online learning system, unreliable grading system and promotion to next semester. Similarly, Kerr (2020) also reported that "TJ Annerino, a junior at Auburn University in Alabama, says college students are experiencing more stress as they adjust to a loss of structure in their lives and a new academic playing field in the form of online classes"(n.p).

\section{Conclusion}

The study was a psychological analysis and was conducted to investigate the stress levels and types of stress experienced by doctors, teachers, engineers and students during COVID-19 outbreak. The results demonstrated that more than half of surveyed population is facing psychological stress and others are facing financial, academic and emotional stress in varying degrees respectively as has been analyzed in discussion section. The study revealed that COVID -19 exercised a negative stress impact on these professionals and they were facing acute level stress. This study would be helpful for the future researchers who would proceed to do research in COVID-19 Studies. As this study unearthed only the concerns and stresses of professionals regarding 4 fields thus, there are still areas which are left unexplored. In future, a psychological study regarding the stress experienced by children and youngsters during Corona spread can be navigated. Furthermore, a study based on how stress is affecting elder people and household servants in homes and people from low strata's: daily wagers (auto driver, vendors, garbage pickers etc) can be conducted. There are more areas yet to be explored.

\section{Recommendations}

I. People should indulge themselves in different positive pastime hobbies to ward off the effects of stress; gardening, reading, cooking, watching movies etc.

II. The focus on self-philosophy should be adopted through channels like yoga, walk and meditation. They will help minimize or overcome physiological 
and psychological stress. Meditation and yoga are always elixir to eliminate negative energies in humans.

III. A special care should be given to healthy diet to boost metabolism and body immune system and energy. A half an hour exercise, swimming and ti-chi or any such art or physical activity should be practiced to keep body active and healthy.

IV. Sharing and talk to family members, friends, peers and colleagues prove to be cathartic. It helps overcoming fear of falling prey to disease as the feeling of not being alone takes place through sharing.

V. To mitigate stress levels of teachers and students, online webinars, teaching sessions and workshops can be organized which impart knowledge of digital learning and teaching strategies to teachers and learners.

VI. Stress management Sessions (virtually) can be organized to make people familiar with stress coping strategies.

VII. Besides, government and WHO should play its role through media advertisements, radio and TV programmes to impart understanding to masses about stress management and necessary precautions concerning outbreak. 


\section{References}

Association, American Psychiatric, (2013). Diagnostic and statistical manual of mental disorders. American Psychiatric Publishing.

Bhat, B. A., Khan, S., Manzoor, S., Niyaz, A., Tak, H. J., Anees, S.-U.-M., Ahmad, I. (2020). A study on impact of COVID-19 lockdown on psychological health, economy and Social life of people in kashmir. International Journal of Science and Healthcare Research, 05(2), 36-46.

Cipriano, C., \& Brackett, M. (2020). Human elements in the virtual classroom. On Teaching and Learning.https://www.edsurge.com/news/2020-04-07-teachers-areanxious-and-overwhelmed-they-need-sel-now-more-than-ever.

Collie,R.J., Martin,A.J.(April 2020).Teacher wellbeing during COVID 19.ACR Teacher Magazine. https://www.teachermagazine.com.au/articles/teacher-wellbeing-during covid 19

Cohen, L., Manion, L., \& Morrison, K. (2007). Research Methods in Education. USA, Canada: Routledge.

Fardin, M. A. (2020). COVID-19 and anxiety: A review of psychological impacts of infectious disease outbreaks. Archives of Clinical Infectious Diseases, 15(COVID19).https://www.researchgate.net/publication/340378745_COVID19_and_Anxiety_ A_Review_of_Psychological_Impacts_of_Infectious_Disease_Outbreaks

Gewertz, C. (2020, April). Exhausted and Grieving: Teaching During the Coronavirus Crisis. Education Week. https://www.edweek.org/ew/articles/2020/04/16/exhaustedand-grieving-teaching-during-the-coronavirus.html.

Gautam, R., \& Sharma, M. (2020). 2019-n CoV pandemic: A disruptive and stressful atmosphere for Indian academic fraternity. Brain, Behavior, and Immunity. https://search.yahoo.com/search?fr=mcafee \& type=E210US91215G91319\&p=2019$\mathrm{nCoV}+$ pandemic $\% 3 \mathrm{~A}+\mathrm{A}+$ disruptive+and+stressful+atmosphere+for+Indian+acade mic+fraternity.

Kerr, E. (2020). How college students manage coronavirus stress. US News \&World Report. https://www.usnews.com/education/best-colleges/articles/how-collegestudents-are-managing-coronavirus-stress.

Kumari, M., Badrick, E., Chandola, T., Adam, E. K., Stafford, M., Marmot, M. G., \&Kirschbaum, C. (2009). Cortisol secretion and fatigue: associations in a community-based cohort. Psycho-neuroendocrinology, 34(10), 1476-1485. https://www.scholars.northwestern.edu/en/publications/cortisol-secretion-andfatigue-associations-in-a-community-based- 
McEwen, B. S., \& Morrison, J. H. (2013). Brain on Stress: Vulnerability and plasticity of the prefrontal cortex over the life course. US National Library of Medicine National Institute of Health, 16-29. https://journals.sagepub.com/doi/10.1177/1745691613506907

Mian, A. (2020, June). Covid-19 Stress: Dawn.

Marshall, R. D., Yehuda, R., \& Bone, S. (2000). Trauma-focused psychodynamic psychotherapy for individuals with post-traumatic stress symptoms.International Handbook of Human Response to trauma (347-361). Springer, Boston, MA.

McFarlane, A. C. (2000). Traumatic stress in the 21st century. Australian \& New Zealand Journal of Psychiatry, 34(6), 896-902.

Shams, S., \&S.Khan. (2020, June). Coronavirus: Pakistani Govt Lays off Thousands of Workers to Revive Economy. The Wire: https://thewire.in/south-asia/coronaviruspakistan-govt-steel-mills.

Shahsavarani, A. M., Azad Marz Abadi, E., \& Hakimi Kalkhoran, M. (2015). Stress: Facts and theories through literature review. International Journal of Medical Reviews, 2(2), 230-241.

Ozamiz-Etxebarria, N., Dosil-Santamaria, M., Picaza-Gorrochategui, M., \& IdoiagaMondragon, N. (2020). Stress, anxiety, and depression levels in the initial stage of the COVID-19 outbreak in a population sample in the northern Spain. Cadernos de Saúde Pública, 36, e00054020. doi: 10.1590/0102-311X00054020.

Urooj, U., Ansari, A., Siraj, A., Khan, S., \& Tariq, H. (2020). Expectations, Fears and Perceptions of doctors during Covid-19 Pandemic.Pakistan Journal of Medical Sciences, 36 (COVID19-S4).37-42.

Vahia, V. N. (2013). Diagnostic and statistical manual of mental disorders 5: A quick glance. Indian Journal of Psychiatry, 55(3), 220-223. 